\title{
Tandem transformations of 1,2,4-triazol-5-ylidenes into 5-amidino-1,2,4-triazoles
}

\author{
Nikolai I. Korotkikh, ${ }^{\text {** Nataliya V. Glinyanaya, }}$ Alan H. Cowley, ${ }^{\mathrm{b}} *$ Jennifer A. Moore, \\ Arthur V. Knishevitsky, ${ }^{\text {a }}$ Tatyana M. Pekhtereva, ${ }^{a}$ and Oles P. Shvaika ${ }^{a}$ \\ ${ }^{a}$ Department of Chemistry of Nitrogen Containing Heterocyclic Compounds, the L. M. \\ Litvinenko Institute of Physical Organic and Coal Chemistry, Ukrainian Academy of Sciences, \\ 70, R. Luxemburg, Donetsk, 83114, Ukraine \\ ${ }^{b}$ Department of Chemistry \& Biochemistry, the University of Texas at Austin, 1 University \\ Station A5300, Austin, Texas 78712-0165, USA \\ E-mail:nkorotkikh@ua.fm,cowley@mail.utexas.edu
}

\begin{abstract}
The first tandem autotransformations of heteroaromatic carbenes have been found. These reactions involve cleavage of the 1-tert-butyl-3,4-diaryl-1,2,4-triazol-5-ylidenes 1a-d to form benzonitriles and the respective carbodiimides, followed by further reactions of the latter with carbenes 1a-d to afford the 3,4-diaryl-5-(1-tert-butyl-3-arylamidin-2-yl)-1,2,4-triazoles 5a-d. The X-ray structures of the carbene 1-tert-butyl-3-phenyl-4- $n$-bromophenyl-1,2,4-triazol-5ylidene (1a) and the amidinotriazole 3-phenyl-4- $p$-bromophenyl-5-(1-tert-butyl-3- $p$ bromophenylamidin-2-yl)-1,2,4-triazole (5a) were determined. The reactions of 1a with the electrophiles diphenylcarbodiimide, acetonitrile, and diphenyldiazomethane are also described.
\end{abstract}

Keywords: Carbenes, cleavage reactions, tandem autotransformations, triazoles

\section{Introduction}

Proton migration processes are known to take place with simple carbenes and such processes can proceed even at low temperatures. ${ }^{1}$ Proton migration also occurs with N-heterocyclic carbenes ${ }^{2}$ and, for example, the 1,2-H migration of imidazol-2-ylidenes leads to the corresponding imidazoles. Later, it was discovered experimentally ${ }^{3}$ that apparent 1,2-silyl migrations of aromatic carbenes occur by intermolecular in situ silyl exchanges, while theoretical studies ${ }^{4}$ suggest that 1,2-silyl migration proceeds via nucleophilic attack by the carbene lone pair at silicon. Recently, a transient tropylidene-substituted N-heterocyclic carbene has been reported which undergoes rearrangement to the corresponding 2-substituted imidazole. ${ }^{5}$ The migration of acyl and phosphoryl groups on to ylidic (carbene) centers during the in situ acylation and 
phosphorylation of azoles in the presence of bases has also been described. ${ }^{6}$ More information concerning carbene transformations and organocatalysis by carbenes can be found in recent review articles. ${ }^{2,7,8}$ However, the thermal decompositions of stable heteroaromatic carbenes have not been reported yet, even though the instability of heterocyclic carbenes upon heating has been noted in several publications. ${ }^{9-11}$

In the present work we describe (i) the synthesis of new mixed (aliphatic and aromatic) substituted stable carbenes of the triazole series, i.e. 1-tert-butyl-3,4-diaryl-1,2,4-triazol-5ylidenes; (ii) the first tandem autotransformations of 1,2,4-triazol-5-ylidenes (i.e. their own transformation without the participation of other reagents) to 5-amidino-1,2,4-triazoles; (iii) the reactions of the indicated carbenes with 1,3-diphenylcarbodiimide, oxygen, acetonitrile and diphenyldiazomethane; (iv) the X-ray crystal structures of 1-tert-butyl-3-phenyl-4- $p$ bromophenyl-1,2,4-triazol-5-ylidene (1a) and 3-phenyl-4- $p$-bromophenyl-5-(1-tert-butyl-3-pbromophenylamidin-2-yl)-1,2,4-triazole (5a).

The new heteroaromatic carbenes of the triazole series with a tert-butyl substituent at the 1 position, namely the 1-tert-butyl-3,4-diaryl-1,2,4-triazol-5-ylidenes 1a-d, were synthesized in two steps. In the first step, 1,2,4-triazolium salts 3a-d were synthesized in high yields (72$88 \%$ ) by quaternization of the corresponding 1,2,4-triazoles $\mathbf{2 a - d}$ with tert-butyliodide. The desired carbenes 1a-d were then produced in good to high yields $(55-81 \%)$ by further deprotonation of the salts $\mathbf{3 a}-\mathbf{d}$ with potassium tert-butoxide or isopropoxide in THF solution or in a toluene/isopropanol mixed solvent.

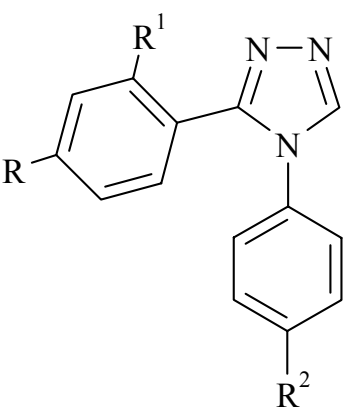

2a-d

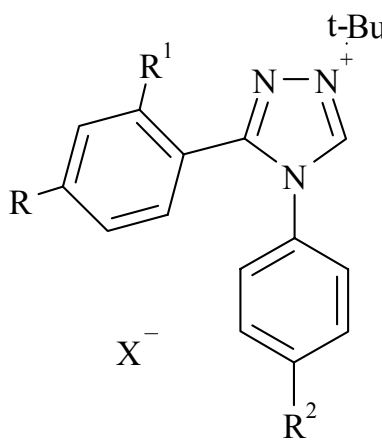

3a-d

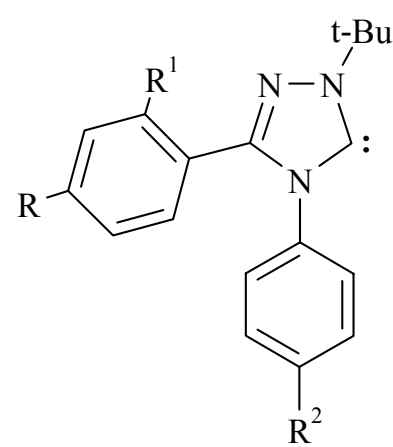

1a-d

1-3 a. $R=R^{1}=H, R^{2}=B r ; b . R=R^{1}=R^{2}=H$; c. $R=R^{2}=B r, R^{1}=H$; d. $R=H, R^{1}=C l$; $\mathrm{R}^{2}=\mathrm{Br}$

\section{Results and Discussion}

The most widely used approach for the synthesis of stable carbenes, published originally by Arduengo et al., ${ }^{12}$ involves the deprotonation of imidazolium salts with potassium tert-butoxide in THF solution. The method used here (procedure A) differs from that of Arduengo et al. in that, after the deprotonation reaction, the resulting dispersion is evaporated to dryness and the 
carbene product is separated from the inorganic salt by repeated THF or toluene extractions. This modification allows the azolium alkoxide decomposition to the carbene and alcohol to be carried out in high yield. The yield of $\mathbf{1 a}$ is typically $81 \%$ while the yields of compounds $\mathbf{1 b}$-d are somewhat smaller $(57-74 \%)$.

A lesser-used method (procedure B) involves conducting the deprotonation reactions in aromatic solvents. Details of this procedure can be found in references 13 and 14 . In the presence of alcohol three types of products can be formed, namely azolium alkoxides ${ }^{14}$ or their undissociated forms, alkoxyazolines ${ }^{9}$ and H-complexes NHC...HOAlk. Semi-empirical calculations using the PM-3 method revealed that the energies of the alkoxyazoline and the isomeric H-bond complex are almost equal in isopropyl alcohol solution. In the solvents methanol and tert-butanol, the alkoxyazolines become favored by $24-25 \mathrm{kcal} / \mathrm{mol}$. The complete decomposition of the indicated intermediate $3(\mathrm{X}=i$-PrO) occurs readily by removal of the toluene under reduced pressure to afford carbene 1a in high yields $(\sim 81 \%)$. Thus, the role of alcohol in this modification of the carbene synthesis avoids the isolation of the intermediates and protects the carbene center upon deprotonation. The related transformation was carried out in two steps by Enders and co-workers ${ }^{9}$ and was completed by decomposition of the pure methoxytriazoline.

The new compounds were characterized by elemental analysis, ${ }^{1} \mathrm{H}$ and ${ }^{13} \mathrm{C} \mathrm{NMR}$ spectroscopy. The ${ }^{1} \mathrm{H}$ NMR spectra of salts 3a-d in DMSO-d $\mathrm{d}_{6}$ show specific signals for the $\mathrm{C}(5) \mathrm{H}$ proton in the range $\delta 10.6-10.7 \mathrm{ppm}$. The resonances for the tert-butyl group $(\delta 1.72-$ $1.76 \mathrm{ppm})$ and aromatic protons $(\delta 7.4-7.8 \mathrm{ppm})$ are also observed. The ${ }^{1} \mathrm{H}$ NMR spectra of carbenes 1a-d exhibit resonances for the tert-butyl protons $(\delta 1.77-1.82 \mathrm{ppm})$ and aromatic rings $(\delta 6.9-7.4 \mathrm{ppm})$. The ${ }^{13} \mathrm{C}$ NMR spectra of compounds 1a-d display signals for the tertbutyl carbon atoms (in the range $\delta 30-31$ and $59-60 \mathrm{ppm}$ ), as well as signals for the aromatic groups $(\delta 121-140 \mathrm{ppm})$. The triazole nucleus exhibits resonances for the $\mathrm{C}(3)(\delta 148.0-$ $151.3 \mathrm{ppm})$ and $\mathrm{C}(5)$ carbon atoms $(\delta 206.4-211.0 \mathrm{ppm})$ (cf., for the related triphenylsubstituted Enders' carbene the chemical shift is $\delta 214.0 \mathrm{ppm}$ ).

Crystals of carbene 1a suitable for X-ray diffraction study were grown from toluene solution. A depiction of the molecular structure of $\mathbf{1 a}$ is presented in Fig. 1. 


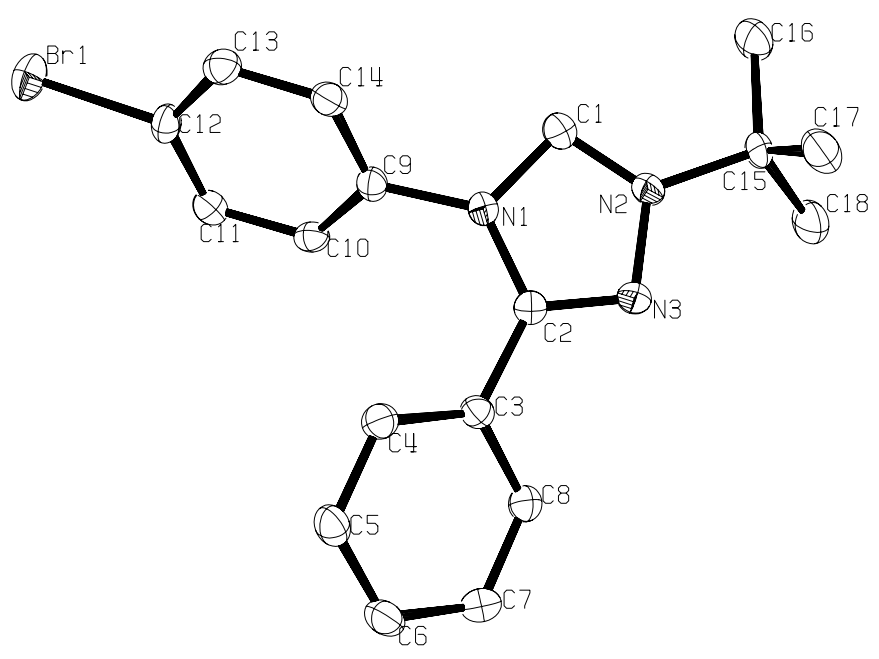

Figure 1. View of carbene 1a showing thermal ellipsoids at 50\% probability.

In general, the metrical parameters for 1a are similar to those for carbene 4, which was synthesized and structurally characterized earlier. ${ }^{13}$ As usually observed for heteroaromatic carbenes of this type, the triazole ring of compound 1a is almost planar (Fig. 1). The N(1)-C(1) and $\mathrm{C}(2)-\mathrm{N}(1)$ bond lengths for $\mathbf{1 a}$ are somewhat shorter but the $\mathrm{C}(2)-\mathrm{N}(3)$ bond length somewhat longer than those for 4 (see Fig. 1 for the atom numbering scheme and Table 1). This trend suggests a higher bond multiplicity in the case of carbene 1a. The bond order $p$ (calculated from the linear dependence of bond orders and bond lengths ${ }^{15}$ ) for $\mathrm{N}(2)-\mathrm{C}(1)$ in this compound is 1.799 (cf., for $4 p=1.736$, and for the Enders carbene, 1,3,4-triphenyl-1,2,4-triazol-5-ylidene, $p$ $=1.707$ ) thus indicating that the largest contribution of the ylidic resonance occurs in the case of 1a (cf., for Arduengo's 1,3-diadamantylimidazol-2-ylidene the related bond orders $p$, calculated by us and based on the X-ray data from reference 12 , are 1.580 and 1.626 for the $\mathrm{C}(2)-\mathrm{N}(1)$ and $\mathrm{N}(1)-\mathrm{C}(1)$ bonds, respectively, and for 1,3-diadamantylbenzimidazol-2-ylidene the $p$ values are 1.575 and 1.586 , respectively). ${ }^{14,16}$ On the other hand, the $\mathrm{N}(2)-\mathrm{N}(3)$ bond is slightly delocalized $(p=1.287)$ but marginally more so than in Enders' carbene $(p=1.262)$. The other bond orders are similar to those of well known carbenes (for 1a, $p$ for $\mathrm{N}(1)-\mathrm{C}(1)=1.494, p$ for $\mathrm{C}(2)-\mathrm{N}(1)=$ 1.546 , and $p$ for $\mathrm{C}(2)-\mathrm{N}(3)=1.966)$.

The bond angle at the carbene carbon atom $\mathrm{C}(1)$ of $\mathbf{1 a}\left(100.7^{\circ}\right)$ is larger than that for $\mathbf{4}$, but the same as that for the Enders carbene within experimental error (100.6 deg). The aromatic rings attached to $\mathrm{C}(2)$ and $\mathrm{N}(1)$ are less twisted relative to the heterocyclic ring than in the case of carbene 4. The $\mathrm{C}(2)-\mathrm{C}(3)$ bond order of $p=1.279$ is notably larger than that for $\mathrm{N}(1)-\mathrm{C}(9)$ ( $p$ $=1.236$ ) but both values are closer to each other in comparison with those for carbene 4 , for which $p=1.310$ and 1.224 , respectively. 
Table 1. Selected bond lengths $(\AA)$ and internal $(\theta$, deg) and torsion angles $(\varphi, \operatorname{deg})$ for carbenes 1a and $\mathbf{4}$ as determined by single crystal $\mathrm{X}$-ray diffraction

\begin{tabular}{lll}
\hline Bonds or angles & $\mathbf{1 a}$ & $\mathbf{4}$ \\
\hline $\mathrm{C}(1)-\mathrm{N}(2)$ & $1.335(3)$ & $1.346(3)$ \\
$\mathrm{C}(2)-\mathrm{N}(3)$ & $1.306(3)$ & $1.301(3)$ \\
$\mathrm{C}(1)-\mathrm{N}(1)$ & $1.388(3)$ & $1.386(3)$ \\
$\mathrm{C}(2)-\mathrm{N}(1)$ & $1.379(3)$ & $1.384(3)$ \\
$\mathrm{N}(2)-\mathrm{N}(3)$ & $1.393(3)$ & $1.394(3)$ \\
$\mathrm{C}(2)-\mathrm{C}(3)$ & $1.479(3)$ & $1.473(3)$ \\
$\mathrm{C}(9)-\mathrm{N}(1)$ & $1.433(3)$ & $1.435(3)$ \\
$\mathrm{C}(15)-\mathrm{N}(2)$ & $1.489(3)$ & $1.480(3)$ \\
$\mathrm{C}(15)-\mathrm{C}(16)$ & $1.520(4)$ & $1.528(3)$ \\
$\mathrm{C}(12)-\mathrm{Br}(1)$ & $1.897(2)$ & $1.903(2)$ \\
$\theta \mathrm{N}(2)-\mathrm{C}(1)-\mathrm{N}(1)$ & $100.7(2)$ & $100.3(2)$ \\
$\theta \mathrm{N}(2)-\mathrm{N}(3)-\mathrm{C}(2)$ & $103.4(2)$ & $103.4(2)$ \\
$\varphi \mathrm{C}(2)-\mathrm{N}(1)-\mathrm{C}(9)-\mathrm{C}(10)$ & $-51.1(2)$ & $-125.8(2)$ \\
$\varphi \mathrm{N}(3)-\mathrm{C}(2)-\mathrm{C}(3)-\mathrm{C}(4)$ & $-29.9(2)$ & $-140.1(2)$ \\
\hline
\end{tabular}

In order to estimate the thermal stabilities of carbenes 1a-d, these compounds were heated in small amounts of decane or 1,3,5-triethylbenzene. As shown in Scheme 1, an unusual thermal autotransformation took place to afford the amidinotriazoles 5a-d. The product yields varied considerably depending on the reaction conditions. The highest yields were realized in the temperature range $130-170{ }^{\circ} \mathrm{C}$. For example, heating the sample at $170{ }^{\circ} \mathrm{C}$ for $8 \mathrm{~h}$ resulted in a $28 \%$ yield of triazole $\mathbf{5 a}$, while heating at $150{ }^{\circ} \mathrm{C}$ for $10 \mathrm{~h}$ afforded a $49 \%$ yield of $\mathbf{5 a}$, and heating at $130{ }^{\circ} \mathrm{C}$ for $38 \mathrm{~h}$ and $140{ }^{\circ} \mathrm{C}$ for $8 \mathrm{~h}$ caused the yield of 5a to increase to $70 \%$. Below $130{ }^{\circ} \mathrm{C}$ the rate of the reaction is very slow. The use of the mildest set of conditions does not result in a quantitative yield of the product $\mathbf{5 a}$. Nevertheless, in the case of triazole $\mathbf{5 c}$ a high yield was achieved (81\%).

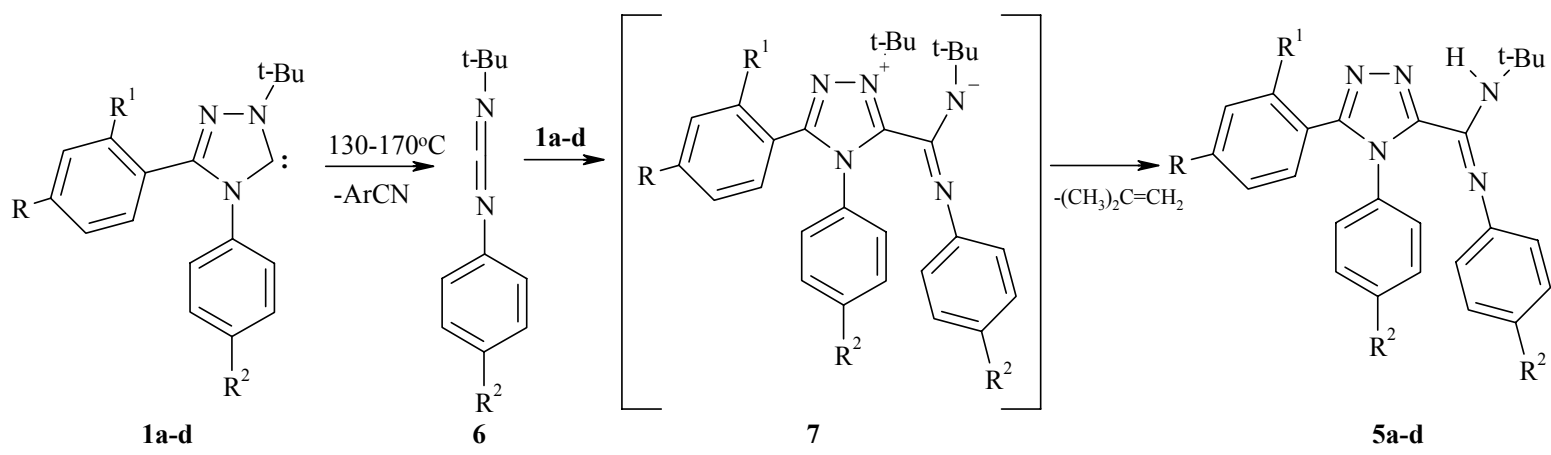

5 a. $\mathrm{R}=\mathrm{R}^{1}=\mathrm{H}, \mathrm{R}^{2}=\mathrm{Br} ; \mathbf{b} \cdot \mathrm{R}=\mathrm{R}^{1}=\mathrm{R}^{2}=\mathrm{H} ; \mathbf{c} \cdot \mathrm{R}=\mathrm{R}^{2}=\mathrm{Br}, \mathrm{R}^{1}=\mathrm{H} ; \mathbf{d} \cdot \mathrm{R}=\mathrm{H}, \mathrm{R}^{1}=\mathrm{Cl}$; $\mathrm{R}^{2}=\mathrm{Br} ; 6 \mathrm{R}^{2}=\mathrm{Br}$

\section{Scheme 1}


It is clear that the end product of this induced transformation results from the interaction of the thermal decomposition product, carbodiimide $\mathbf{6}$, with the starting carbene $\mathbf{1}$, followed by stabilization due to dealkylation of the zwitterionic intermediate 7 to form additionally isobutene. This carbene transformation is feasible only when the rate of the interaction $\mathbf{1}+\mathbf{6}$ is significantly greater than the rate of thermal decomposition of carbene $\mathbf{1} \rightarrow \mathbf{6}+\mathrm{ArCN}$, otherwise a significant amount of carbodiimide would remain or only carbodiimide $\mathbf{6}$ and nitriles would be produced. Nevertheless, at elevated temeperatures (approximately $170{ }^{\circ} \mathrm{C}$ ) the carbenes 1 probably undergo cleavage by a rapid intramolecular process such that there is insufficient time for reaction with carbodiimides 6 to take place via an intermolecular process. In this case, the major products of the reaction are nitriles and carbodiimides, $\mathbf{6}$.

The products of the carbene decomposition were isolated from the mother liquor following the isolation of compound 5a. Based on ${ }^{1} \mathrm{H}$ and ${ }^{13} \mathrm{C}$ NMR spectroscopic data, TLC, and gas chromatography assays, the products of the carbene cleavage are carbodiimide $\mathbf{6}$ and benzonitrile. The conclusion concerning the formation of carbodiimide 6 was confirmed by carrying out the reaction of the mother liquor components with carbene $1 \mathbf{a}$ at $100{ }^{\circ} \mathrm{C}$, i.e. under the conditions in which carbene 1a is not decomposed. The isolation of amidinotriazole $\mathbf{5 a}$ in $47 \%$ yield (part of compound 5a was not isolated from the reaction mixture) also supports the formation of carbodiimide $\mathbf{6}$ and the proposed pathway for the reaction. The related carbenes $\mathbf{1 b}$ d $(\mathrm{R}=\mathrm{H})$ react via a similar pathway to afford $51-81 \%$ yields of triazoles $\mathbf{5 b}$-d. However, it should be noted that the reaction of compound $\mathbf{1 b}$ proceeds at higher temperatures $\left(150-170{ }^{\circ} \mathrm{C}\right)$. The structures of the triazoles 5a-d were established on the basis of ${ }^{1} \mathrm{H} N M R$ and ${ }^{13} \mathrm{C}$ NMR spectroscopic data. The triazoles $\mathbf{5 a , c , d}$ were characterized by mass spectrometry and the structure of compound 5a was determined by X-ray crystallography. The ${ }^{1} \mathrm{H}$ NMR spectra of triazoles 5a-d show resonances for the tert-butyl $(\delta 1.62-1.66 \mathrm{ppm})$ and aromatic protons $(\delta 6.1$ - $7.6 \mathrm{ppm}$ ). The N(5)-H proton NMR signals were observed in the same range as those of the aromatic protons; nevertheless, in the cases of compounds 5a,c,d a broadened signal was detected at $\delta 6.45-6.59 \mathrm{ppm}$. This resonance disappeared in the presence of triethylamine or upon heating due to the acceleration of proton exchange, thus confirming the proposed assignment. The ${ }^{13} \mathrm{C}$ NMR spectrum featured the characteristic resonances for the triazole ring carbon atoms $\mathrm{C}(1)$ and $\mathrm{C}(2)$ in the range $\delta 147.4-150.4 \mathrm{ppm}$ and signals for the phenylimino $C(15)-\mathrm{N}(5)$ atom $(\delta 151.8-152.8 \mathrm{ppm})$ (see Fig. 2 for the atom numbering scheme). Also noteworthy are the chemical shifts of the ipso-carbon atoms, $C(9)-\mathrm{N}(1)$, of the $\mathrm{N}$-aromatic quaternary atoms $(\delta 143.2-143.6 \mathrm{ppm})$. The C-amidine resonances for compounds 5a-d are estimated to be in the range $\delta 124.7-125.7 \mathrm{ppm}$. The mass spectra of compounds $\mathbf{5 a , c , d}$ exhibit the molecular ions $\left[\mathrm{M}^{+}\right]$or $\left[\mathrm{MH}^{+}\right]$corresponding to the monomers $(\mathrm{m} / \mathrm{z} 554,632$ and 588, respectively). The presence of benzonitrile in the reaction mixture was evidenced by direct comparison of its physical properties $\left({ }^{1} \mathrm{H}\right.$ NMR spectrum, boiling point, refractive index) with those of an authentic sample; the evolution of isobutene was confirmed by a ${ }^{1} \mathrm{H}$ NMR spectroscopic assay of a $\mathrm{CDCl}_{3}$ solution of the gaseous products). 
Crystals of triazole 5a suitable for X-ray diffraction study were grown from octane or decane solution. The X-ray analysis of compound 5a confirms the presence of an uncharged triazole nucleus and the absence of a tert-butyl group at the triazole nucleus that was present in the structure of starting carbene 1a (Fig. 2 and 3). A noteworthy redistribution of the electron density in the triazole ring is apparent from the metrical parameters of the amidine fragment $(r \mathrm{C}=\mathrm{N}$ $1.280 \AA, \mathrm{C}-\mathrm{N} 1.347 \AA, \mathrm{C}(15)-\mathrm{N}(5) 1.402 \AA)$. The $\mathrm{N}(4) \mathrm{H}$ proton of the amidine group does not form a hydrogen bond with triazole nitrogen atom $\mathrm{N}(3)$.

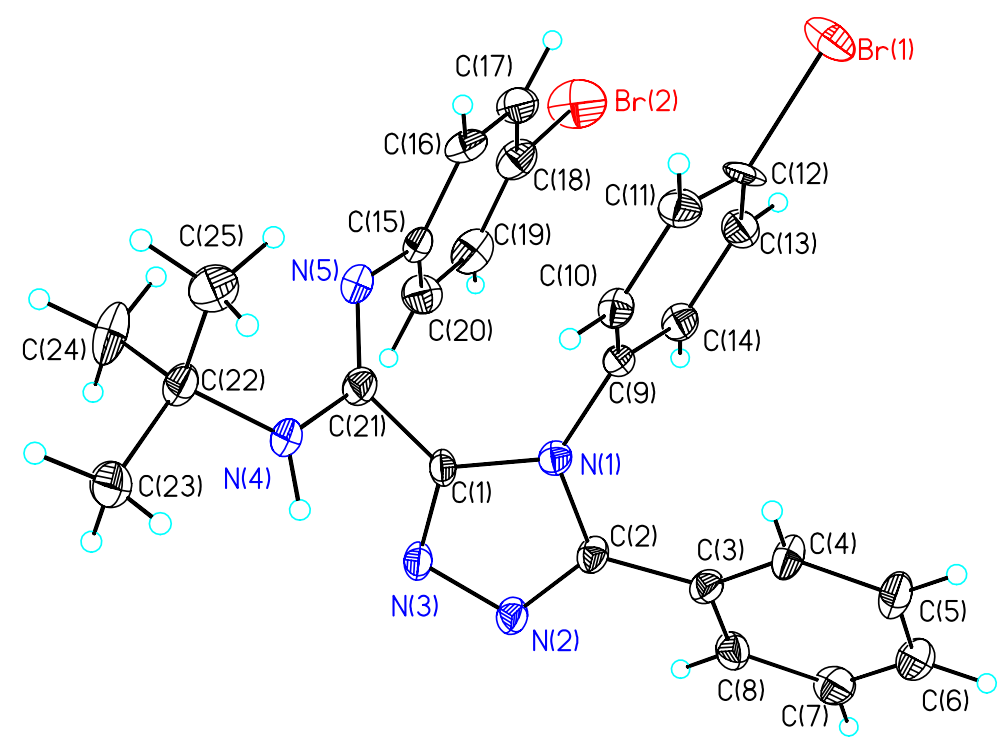

Figure 2. View of triazole 5a showing thermal ellipsoids at 50\% probability.

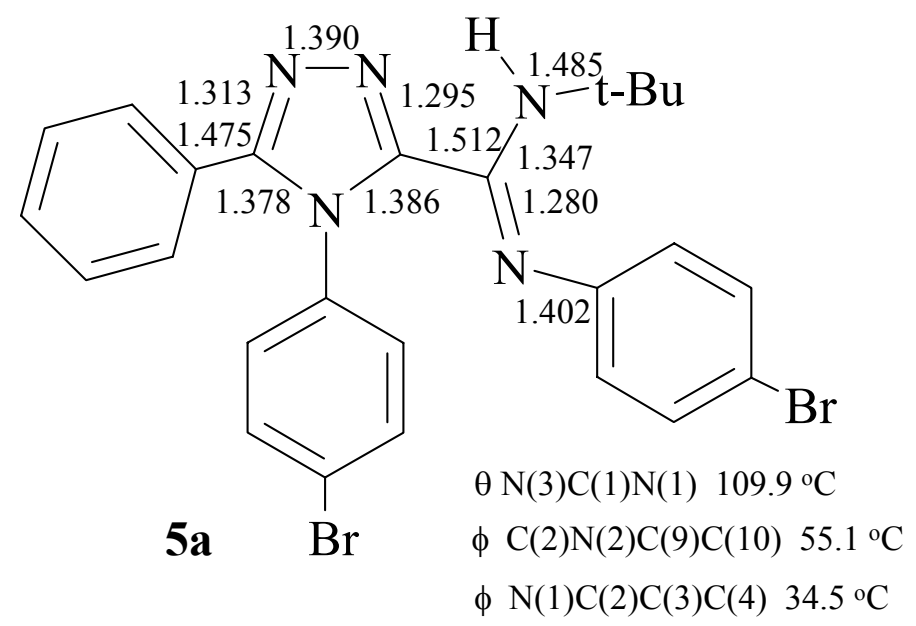

Figure 3. Selected bond lengths $(\AA)$, internal angles $(\theta$, deg) and torsion angles $(\varphi, \operatorname{deg})$ for triazole $\mathbf{5 a}$ as determined by single-crystal X-ray diffraction. 
It is interesting to note that the strongest interaction of the aromatic rings with the conjugated triazole and amidine fragments is observed for the arylamidine group. For the $\mathrm{C}(15)-\mathrm{N}(5)$ bond $p$ $=1.414$. The bond orders for the other aromatic groups on the triazole ring are not increased as much: $\mathrm{C}(9)-\mathrm{N}(1) p=1.155$, for $\mathrm{C}(21)-\mathrm{C}(1) p=1.112$, and for $\mathrm{C}(2)-\mathrm{C}(3) p=1.299$ due to twisting of the various rings with respect to each other. Note that the aryl groups attached to the 3,4 positions are twisted by $34.5^{\circ}$ and $55.1^{\circ}$, respectively, with respect to the plane of the triazole ring. The amidine fragment is twisted by $54.4^{\circ}$ with respect to the plane of the triazole ring.

The ${ }^{1} \mathrm{H}$ NMR spectrum of carbodiimide 6 exhibits signals for the tert-butyl group $(\delta 1.65$ $\mathrm{ppm})$ and the aromatic protons $(\delta 7.2-7.6 \mathrm{ppm})$ (the latter showing specific spin-spin coupling that is appropriate for the 4-substituted aromatic nuclei, $J=8.6 \mathrm{~Hz}$ ). The ${ }^{13} \mathrm{C}$ NMR spectrum displays the characteristic signal for the carbodiimide carbon atom $(\delta 135.50 \mathrm{ppm})$, along with the resonances for the tert-butyl carbon atom $(\delta 31.6$ and 57.7), the ipso-carbon atom $\mathrm{C}-\mathrm{Br}(\delta$ $117.4 \mathrm{ppm})$ and the ipso-carbon atom $\mathrm{C}-\mathrm{N}(\delta 140.3 \mathrm{ppm})$.

The nature of the carbodiimide that is formed plays an important role in the successful outcome of the reaction. In this case, the alkylarylcarbodiimides 6 are obtained that react readily with the carbene to afford amidinotriazoles 5 at elevated temperatures. When the reaction of diphenylcarbodiimide with carbene 1a was carried out, the same process was more facile and the resulting zwitterionic compound reacted rapidly with another molecule of carbodiimide 6 to form the triazolo-spiro-imidazolidine $\mathbf{8}$ even at room temperature. This type of transformation is well known in the case of the reactions of carbenes with isocyanates or isothiocyanates ${ }^{2,11}$ but not in the case of carbodiimides. Given the foregoing, aliphatic derivatives of carbodiimides should react even slower than alkylarylcarbodiimides. In fact, an aliphatic analogue of 6 , dicyclohexylcarbodiimide, does not form stable products with carbene 1a unless the temperature exceeds $100{ }^{\circ} \mathrm{C}$. Nevertheless, the more active imidazol-2-ylidenes react with carbodiimides to give zwitterionic compounds of type $7 .^{17}$

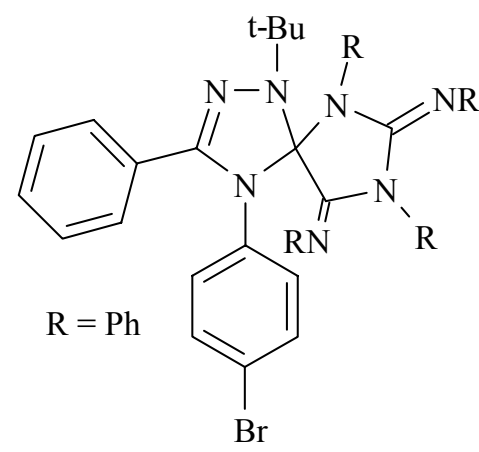

8

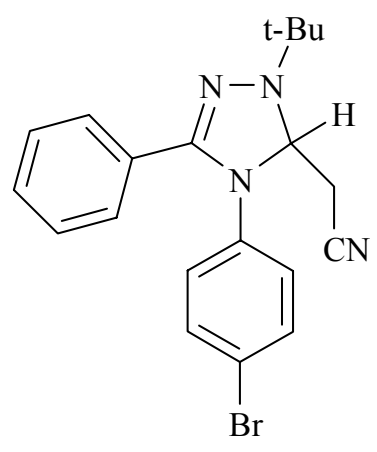

9

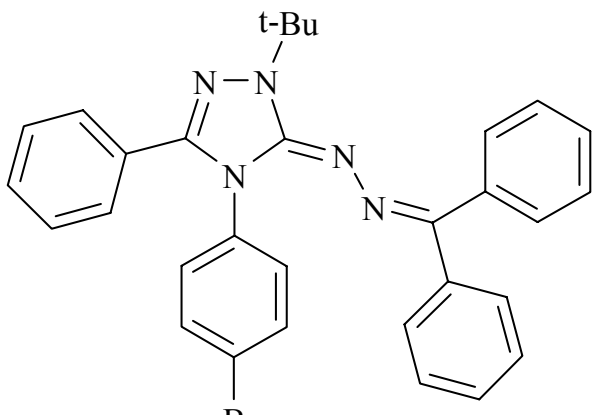

10

In order to explore the reactivity of carbene 1a with electrophiles other than carbodiimides, the reactions of this carbene with acetonitrile and diphenyldiazomethane were carried out. In both cases the reaction occurred rather rapidly at room temperature to afford $36 \%$ and $75 \%$ yields of cyanomethylazoline and azine 10, respectively. It should be noted that the related 1- 
adamantyl-3,4-diarylsubstituted 1,2,4-triazol-5-ylidenes react with acetonitrile more slowly (at $100{ }^{\circ} \mathrm{C}$ for several hours or only slightly at room temperature for 1-2 days). ${ }^{10,13}$ According to our data $^{16,18}$ benzimidazol-2-ylidenes and aromatic-substituted imidazol-2-ylidenes undergo facile insertion reactions (even at room temperature) reminiscent of carbene 1a. Subsequently, Arduengo and co-workers have shown that 4,5-dihydroimidazol-2-ylidenes (but not 1,3diadamantylimidazol-2-ylidene) undergo $\mathrm{C}-\mathrm{H}$ insertion reactions with acetonitrile. ${ }^{19}$ The reaction of the 4,4'-bridged bistriazol-5-ylidene with diphenyldiazomethane in toluene solution (in which it is only slightly soluble) proceeds at $50{ }^{\circ} \mathrm{C}$ for $10 \mathrm{~h} .{ }^{20}$ The formation of the related azines from imidazol-2-ylidenes has also been described. ${ }^{21}$

The transformation $\mathbf{1} \rightarrow \mathbf{5}$ requires strictly anhydrous and oxygen-free conditions. Bubbling triplet oxygen into a THF solution of pure carbene 1a at ambient temperature results in the formation of triazolone 11a as the major product (isolated yield 58\%) (Scheme 2). This result is both interesting and unusual because Denk and co-workers ${ }^{22}$ noted that the related imidazol-2ylidenes are rather stable to oxygen. Moreover, the first triazolylidene of Enders ${ }^{23}$ only reacts with oxygen in refluxing toluene after $24 \mathrm{~h}$. A plausible explanation for the facile transformation of 1a with oxygen is that the reaction proceeds via a triplet-like transition state. Consistent with this proposal, semi-empirical PM-3 calculations reveal that the triplet state of 1a is strongly destabilized.

In the presence of moisture two major side products are formed, namely triazolones $\mathbf{1 1}$ and triazoles 2 (Scheme 3). The possible reason for this observation relates to the facile disproportionation of the intermediate 5-hydroxy-5H-triazoline $\mathbf{1 2}$ into the corresponding triazolone $\mathbf{1 1 b}$ and $5 \mathrm{H}$-triazoline 13, followed by further decomposition of the latter to form isobutane and triazole 2c. The related thermal disproportionation $\mathbf{1 2} \rightarrow \mathbf{1 1}+\mathbf{1 3}$ has been recognized earlier in the case of a benzimidazole series. ${ }^{14}$

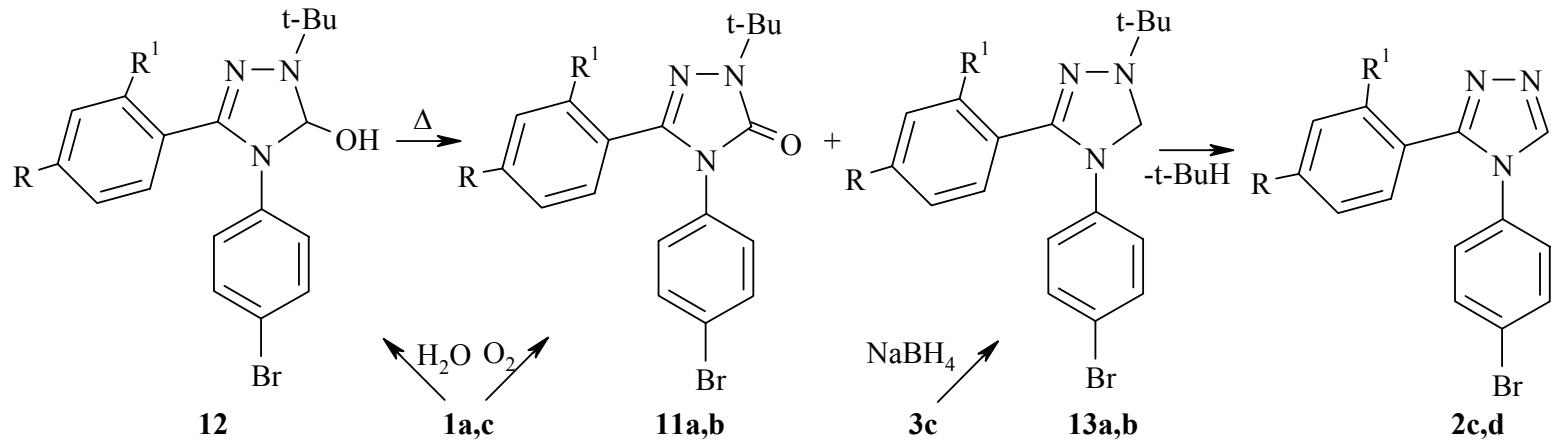

11 a. $R=R^{1}=H$; 11b, 13a. $R=B r, R^{1}=H$; 13b. $R=H, R^{1}=C l$

\section{Scheme 2}

Both side products, the bromo-substituted compounds $\mathbf{1 1 b}$ and $\mathbf{2 c}$, were isolated from the resulting reaction mixture in small quantities and characterized by mass spectrometry $(\mathbf{1 1 b}, \mathrm{m} / \mathrm{z}$ $\left[\mathrm{MH}^{+}\right]$452; 2c, $m / z\left[\mathrm{MH}^{+}\right]$380). The related compound $\mathbf{1 3 b}$ was synthesized independently by 
the reduction of salt $\mathbf{3 d}$ with sodium borohydride in methanol solution. Refluxing $\mathbf{1 3 b}$ in toluene or xylene solution causes transformation to the triazole $2 \mathbf{d}$ due to intramolecular reduction of the tert-butyl group and isobutane elimination.

The ${ }^{1} \mathrm{H}$ NMR spectra of compounds 8-11a exhibit resonances for the tert-butyl group $(\delta 1.43$ $-1.67 \mathrm{ppm})$ and the aromatic protons $(\delta 6.7-7.7 \mathrm{ppm})$. In the ${ }^{13} \mathrm{C}$ NMR spectra, the signals for the tert-butyl carbon atoms fall in the ranges $\delta 27.3-29.5$ and $\delta 57.3-59.2 \mathrm{ppm}$, which are diagnostic for all the indicated compounds. The ${ }^{13} \mathrm{C}$ resonances for the $\mathrm{C}(3)$ atoms $(\delta 151.0$, 144.2 and $152.4 \mathrm{ppm})$ and the $\mathrm{C}(5)$ atoms $(\delta 79.4,149.6$ and $159.9 \mathrm{ppm})$ are characteristic for compounds 9,10, and 11a. The signals for the $\mathrm{Ph}_{2} C$ atoms of azine 10 (153.4 ppm) were also detected.

\section{Conclusions}

In summary, we have demonstrated a new autotransformation of stable carbenes $\mathbf{1} \rightarrow \mathbf{6} \rightarrow \mathbf{7} \rightarrow \mathbf{5}$ that relates to tandem transformations. This is the first observation of such a tandem process in a stable carbene series. The mechanism of this reaction involves an induced reaction due to the formation of the carbodiimides $\mathbf{6}$, followed by further interaction of the latter with carbene $\mathbf{1}$ to afford the zwitterionic intermediates 7 which are stabilized under the reaction conditions by isobutene elimination to form amidinotriazoles $\left(\mathbf{7} \rightarrow \mathbf{5}+\mathrm{i}-\mathrm{C}_{4} \mathrm{H}_{8}\right)$.

The first stage of the tandem reaction $(\mathbf{1} \rightarrow \mathbf{6} \rightarrow \mathbf{7} \rightarrow \mathbf{5})$ probably proceeds via thermal transformation of the singlet carbenes $\mathbf{1}^{1}$ to the triplet triazolylidenes $\mathbf{1}^{3}$ which decompose rapidly to benzonitriles and carbodiimides $\left(\mathbf{1}^{1} \rightarrow \mathbf{1}^{3} \rightarrow \mathbf{6} \rightarrow \mathbf{7} \rightarrow \mathbf{5}\right.$ ). Semi-empirical (PM-3) calculations reveal that in a triplet state triazolylidene 1a undergoes decomposition to benzonitrile and carbodiimide. In this process, the $\mathrm{N}(1)-\mathrm{N}(2)$ and $\mathrm{C}(3)-\mathrm{N}(4)$ bonds are broken, while in the case of the related triphenylsubstituted 1,2,4-triazol-5-ylidene, only the $\mathrm{C}(3)-\mathrm{N}(4)$ bond is ruptured. For the related tetrazol-5-ylidenes, the PM-3 method also predicts decomposition of the molecule into nitrogen and carbodiimide. In fact, tetrazol-5-ylidenes undergo facile in situ decomposition via this route to carbodiimides and nitrogen even at room temperature. ${ }^{24}$ The present 1,2,4-triazol-5-ylidene reaction is initiated in a similar fashion, but at significantly higher temperatures.

\section{Experimental Section}

General Procedures. All experiments with the 1,2,4-triazol-5-ylidenes 1a-d were carried out under an argon atmosphere. All solvents were dried by standard methods prior to use. ${ }^{1} \mathrm{H}$ and ${ }^{13} \mathrm{C}$ NMR chemical shifts are reported relative to tetramethylsilane (TMS, $\delta=0.00$ ) as the internal standard. Mass spectra were measured on an Agilent 1100 Series chromatomass spectrometer (APCI, $3 \mathrm{kV}$ ). The chromatography was carried out on a Zorbax SB Cl8 column with a $95.5 \%$ acetontrile mixture that contained $0.1 \%$ of formic acid. Thin-layer chromatography was 
performed on silica gel with chloroform or a 10:1 mixture of chloroform and methanol as eluent, followed by development with iodine. Elemental analyses were carried out at the Analytical Laboratory of the Litvinenko Institute of Physical Organic and Coal Chemistry. The semiempirical calculations were performed using the MOPAC6 (PM-3) program. The triazoles 2a-c were obtained by the ring transformation of the 2-aryl-1,3,4-oxadiazoles with the corresponding anilines in the presence of trifluoroacetic acid at $180^{\circ} \mathrm{C}$ according to the literature method.$^{25}$

1-tert-Butyl-3-phenyl-4-n-bromophenyl-1,2,4-triazol-5-ylidene (1a). Method A (using THF as solvent). A mixture of the salt $3(1.38 \mathrm{~g}, 3.02 \mathrm{mmol})$ and potassium tert-butoxide $(0.32 \mathrm{~g}, 2.86$ mmol) was stirred with THF $(5 \mathrm{~mL})$ for $1.5 \mathrm{~h}$. The solvent was evaporated and the resinous residue was stirred with petroleum ether until crystallization took place, following which the resulting solid was filtered off and dried. THF $(7 \mathrm{~mL})$ was then added to the solid product and the mixture was stirred for $1 \mathrm{~h}$, following which the inorganic salt was filtered off. The solvent was evaporated from the filtrate from which 1a crystallized. The crystals of 1a were stirred with petroleum ether, filtered off, washed a few times with petroleum ether, then dried to yield $0.83 \mathrm{~g}$ (81\%) of carbene 1a. mp $116-118{ }^{\circ} \mathrm{C}$ (toluene). ${ }^{1} \mathrm{H}$ NMR $\left(\mathrm{C}_{6} \mathrm{D}_{6}, 200 \mathrm{MHz}, 20^{\circ} \mathrm{C}\right): 1.82(\mathrm{~s}, 9 \mathrm{H}$, $\left.\mathrm{CH}_{3} \mathrm{C}\right), 6.90$ (m, 5H, Ar), $7.29 \mathrm{~d}, 7.37 \mathrm{~d}(4 \mathrm{H}, \mathrm{Ar}, J 7.8 \mathrm{~Hz}) .{ }^{13} \mathrm{C}$ NMR $\left(\mathrm{C}_{6} \mathrm{D}_{6}, 50.3 \mathrm{MHz}, 2{ }^{\circ} \mathrm{C}\right)$ : $30.8\left(\mathrm{CH}_{3} \mathrm{C}\right), 59.8$ (ipso-C) $(t-\mathrm{Bu}), 121.0(\mathrm{C}-\mathrm{Br}), 126.9,128.6,129.2,129.6,129.8(\mathrm{Ar}), 131.1$, 140.0 (ipso-C) (Ar), 151.3 (C 3), 207.8 (C 5). Anal. Calcd for $\mathrm{C}_{18} \mathrm{H}_{18} \mathrm{BrN}_{3}$ : C, 60.7; H, 5.1; $\mathrm{Br}$, 22.4; N, 11.8. Found: $\mathrm{C}, 60.4 ; \mathrm{H}, 5.2 ; \mathrm{Br}, 22.2 ; \mathrm{N}, 11.8$.

Method B (using toluene and isopropanol as solvents). A dispersion of salt 3a (8 g, $17.52 \mathrm{mmol})$ and potassium tert-butoxide $(1.88 \mathrm{~g}, 16.79 \mathrm{mmol})$ in a mixture of anhydrous isopropanol (10 $\mathrm{mL}$ ) and anhydrous $(30 \mathrm{~mL})$ toluene was stirred at room temperature for $1.5 \mathrm{~h}$. The solvent was evaporated and the resinous residue was triturated with petroleum ether, and the precipitate that had formed was filtered off and dried. In order to complete the triazolium alkoxide decomposition, the product was extracted with toluene $(15 \mathrm{~mL})$ and the solvent was evaporated again. The precipitate was washed with petroleum ether $(5 \mathrm{~mL})$, filtered off and dried to afford $4.82 \mathrm{~g}(81 \%)$ of carbene $1 \mathrm{a} . \mathrm{Mp} 116-118^{\circ} \mathrm{C}$ (toluene).

1-tert-Butyl-3,4-diphenyl-1,2,4-triazol-5-ylidene (1b) was synthesized by method A from salt 3b. Yield of carbene $\mathbf{1 b} 74 \%$. mp $141-143{ }^{\circ} \mathrm{C}$ (toluene). ${ }^{1} \mathrm{H}$ NMR $\left(\mathrm{C}_{6} \mathrm{D}_{6}, 200 \mathrm{MHz}, 20{ }^{\circ} \mathrm{C}\right) 1.82$ (s, 9H, $\left.\mathrm{CH}_{3} \mathrm{C}\right), 6.90(\mathrm{~m}, 5 \mathrm{H}, \mathrm{Ar}), 7.37(\mathrm{~m}, 5 \mathrm{H}, \mathrm{Ar}) .{ }^{13} \mathrm{C}$ NMR $\left(\mathrm{C}_{6} \mathrm{D}_{6}, 50.3 \mathrm{MHz}, 20{ }^{\circ} \mathrm{C}\right) 31.0$ $\left(\mathrm{CH}_{3} \mathrm{C}\right), 59.6$ (ipso-C)(t-Bu), 126.9, 127.6, 128.5, 128.6, 129.3, 129.5 (Ar), 129.6, 140.4 (ipso-C) (Ar), 151.2 (C 3), 211.0 (C 5). Anal. Calcd for $\mathrm{C}_{18} \mathrm{H}_{19} \mathrm{~N}_{3}$ : C, 78.0; H, 6.9; N, 15.2. Found: C, $78.1 ; \mathrm{H}, 6.8 ; \mathrm{N}, 15.0$.

1-tert-Butyl-3,4-di-p-bromophenyl-1,2,4-triazol-5-ylidene (1c) was obtained by method A from salt $3 \mathbf{c}$ to yield $55 \%$ of carbene 1c. mp $149-151^{\circ} \mathrm{C}$ (toluene). ${ }^{1} \mathrm{H} N M R\left(\mathrm{C}_{6} \mathrm{D}_{6}, 200 \mathrm{MHz}\right.$, $20{ }^{\circ} \mathrm{C}$ ): 1.77 (s, 9H, $\left.\mathrm{CH}_{3} \mathrm{C}\right), 7.01(\mathrm{~m}, 8 \mathrm{H}, \mathrm{Ar}) .{ }^{13} \mathrm{C} \mathrm{NMR}\left(\mathrm{C}_{6} \mathrm{D}_{6}, 50.3 \mathrm{MHz}, 20{ }^{\circ} \mathrm{C}\right): 30.4\left(\mathrm{CH}_{3} \mathrm{C}\right)$, $59.4\left(\right.$ ipso-C) $(t-\mathrm{Bu}), 121.3,124.1(\mathrm{C}-\mathrm{Br}), 128.0,130.4,131.6,131.9(\mathrm{Ar}), 126.0\left(\mathrm{C}^{3} \mathrm{C}\right), 138.4$ $\left(\mathrm{N}^{4} C\right), 149.7\left(\mathrm{C}^{3}\right), 210.0\left(\mathrm{C}^{5}\right)$. Anal. Calcd for $\mathrm{C}_{18} \mathrm{H}_{17} \mathrm{Br}_{2} \mathrm{~N}_{3}$ : C, 49.7; H, 3.9; $\mathrm{Br}, 36.7 ; \mathrm{N}, 9.7$. Found: $\mathrm{C}, 49.6 ; \mathrm{H}, 3.8 ; \mathrm{Br}, 36.9 ; \mathrm{N}, 9.5$. 
1-tert-Butyl-3-o-chlorophenyl-4-p-bromophenyl-1,2,4-triazol-5-ylidene (1d) was obtained according to the above variation of method A from salt $\mathbf{3 d}$ to give $55 \%$ of carbene $\mathbf{1 d}$. $\mathrm{mp} 92$ $94^{\circ} \mathrm{C}$ (toluene). ${ }^{1} \mathrm{H}$ NMR $\left(\mathrm{C}_{6} \mathrm{D}_{6}, 200 \mathrm{MHz}, 20^{\circ} \mathrm{C}\right): 1.77\left(\mathrm{~s}, 9 \mathrm{H}, \mathrm{CH}_{3} \mathrm{C}\right), 7.07(\mathrm{~m}, 2 \mathrm{H}), 7.34(\mathrm{~m}$, $6 \mathrm{H})(\mathrm{Ar}) .{ }^{13} \mathrm{C}$ NMR $\left(\mathrm{C}_{6} \mathrm{D}_{6}, 50.3 \mathrm{MHz}, 20{ }^{\circ} \mathrm{C}\right): 29.8\left(\mathrm{CH}_{3} \mathrm{C}\right), 59.0$ (ipso-C) $(t-\mathrm{Bu}), 120.4(\mathrm{C}-\mathrm{Br})$, $127.0(\mathrm{C}-\mathrm{Cl}), 126.0,127.4,129.2,130.6,131.1,131.4(\mathrm{Ar}), 133.4\left(\mathrm{C}^{3} C\right), 137.7\left(\mathrm{~N}^{4} C\right)(\mathrm{Ar})$, $148.0\left(C^{3}\right), 206.4\left(C^{5}\right)$. Anal. Calcd for $\mathrm{C}_{18} \mathrm{H}_{17} \mathrm{BrClN}_{3}$ : C, 55.3; H, 4.4; Br, 20.5; Cl, 9.1; N, 10.8. Found: C, 55.4; H, 4.4; Br, 20.7; Cl, 9.0; N, 10.9.

Like the triazoles 2a-c, the new derivative 3-o-chlorophenyl-4-p-bromophenyl-1,2,4-triazole 2d was prepared according to the literature method ${ }^{25}$ by the ring transformation of 2-ochlorophenyl-1,3,4-oxadiazole with $p$-bromoaniline in $o$-dichlorobenzene solution in the presence of an equimolar amount of trifluoroacetic acid at $190{ }^{\circ} \mathrm{C}$ for $8 \mathrm{~h}$. The yield of triazole 2d was 53\%. mp $221-223{ }^{\circ} \mathrm{C}$ (toluene). ${ }^{1} \mathrm{H}$ NMR $\left(\mathrm{CDCl}_{3}, 200 \mathrm{MHz}, 20{ }^{\circ} \mathrm{C}\right): 7.03$ (d, 2H), 7.51 $(\mathrm{d}, 2 \mathrm{H})\left(J\right.$ 8.6 Hz), 7.39-7.55 (m, 4H), $8.47(\mathrm{~s}, 1 \mathrm{H}, \mathrm{CHN})$. Anal. Calcd for $\mathrm{C}_{14} \mathrm{H}_{9} \mathrm{BrClN}_{3}: \mathrm{C}, 50.3$; H, 2.7; Br, 23.9; Cl, 10.6; N, 12.6. Found: C, 50.4; H, 2.8; Br, 23.8; Cl, 10.5; N, 12.7.

1-tert-Butyl-3-phenyl-4-p-bromophenyl-1,2,4-triazolium perchlorate (3a). A solution of sodium iodide $(22.5 \mathrm{~g}, 0.15 \mathrm{~mol})$ and tert-butyl chloride $(16.3 \mathrm{~mL}, 0.15 \mathrm{~mol})$ in acetic acid (9 $\mathrm{mL})$ was refluxed for $1.5 \mathrm{~h}$. Triazole $2 \mathrm{a}(15 \mathrm{~g}, 0.05 \mathrm{~mol})$ was then added to the reaction mixture and reflux was continued for $21 \mathrm{~h}$. After the end of the reaction (monitored by TLC) water (60 $\mathrm{mL}$ ), a small quantity of sodium sulfite and activated carbon ( $3 \mathrm{~g})$ were added to the refluxing reaction mixture. After the hot solution had been filtered, sodium perchlorate $(9.18 \mathrm{~g})$ in water $(10 \mathrm{~mL})$ was added; the resulting precipitate was filtered off and dried to give $16.43 \mathrm{~g}(72 \%)$ of salt 3. mp $180-182{ }^{\circ} \mathrm{C}$ (2-ethoxyethanol). ${ }^{1} \mathrm{H}$ NMR 3a (DMSO-d $\left.6,200 \mathrm{MHz}, 20{ }^{\circ} \mathrm{C}\right): 1.76$ (s, $9 \mathrm{H}, \mathrm{CH}_{3} \mathrm{C}$ ), $7.48-7.65$ (m, 9H, Ar), 10.63 (s, 1H, CHN). Anal. Calcd for $\mathrm{C}_{18} \mathrm{H}_{19} \mathrm{BrClN}_{3} \mathrm{O}_{4}$ : C, 47.3; H, 4.2; Br, 17.5; Cl, 7.8; N, 9.2. Found: C, 47.4; H, 4.2; Br, 17.2; Cl, 7.7; N, 9.4.

1-tert-Butyl-3,4-diphenyl-1,2,4-triazolium perchlorate $(3 \mathrm{~b})$ was prepared by the abovementioned method from triazole $\mathbf{2} \mathbf{b}$ and tert-butyl iodide generated in situ in acetic acid to afford $67 \%$ of salt 3b. mp $178-180{ }^{\circ} \mathrm{C}$ (2-ethoxyethanol). ${ }^{1} \mathrm{H}$ NMR (DMSO-d $6,200 \mathrm{MHz}, 20{ }^{\circ} \mathrm{C}$ ): $1.72\left(\mathrm{~s}, 9 \mathrm{H}, \mathrm{CH}_{3} \mathrm{C}\right), 7.38-7.72(\mathrm{~m}, 10 \mathrm{H}, \mathrm{Ar}), 10.63(\mathrm{~s}, 1 \mathrm{H}, \mathrm{CHN})$. Anal. Calcd for $\mathrm{C}_{18} \mathrm{H}_{20} \mathrm{ClN}_{3} \mathrm{O}_{4}$ : C, 57.2; H, 5.3; Cl, 9.4; N, 11.1. Found: C, 57.4; H, 5.2; Cl, 9.2; N, 11.4.

1-tert-Butyl-3,4-di-p-bromophenyl-1,2,4-triazolium perchlorate (3c) was prepared by the method described for salt 3a from triazole 2c and tert-butyl iodide generated in situ in acetic acid. Yield of salt $3 \mathbf{c}=81 \%$. mp $231-233{ }^{\circ} \mathrm{C}$ (water). ${ }^{1} \mathrm{H}$ NMR (DMSO-d $, 200 \mathrm{MHz}, 20{ }^{\circ} \mathrm{C}$ ): 1.75 (s, 9H, $\left.\mathrm{CH}_{3} \mathrm{C}\right), 7.41$ (d, 2H), 7.59 (d, 2H), 7.76 (d, 2H), 7.89 (d, 2H) (J 7.5 Hz, Ar), 10.64 (s, 1H, CHN). Anal. Calcd for $\mathrm{C}_{18} \mathrm{H}_{18} \mathrm{Br}_{2} \mathrm{ClN}_{3} \mathrm{O}_{4}$ : C, 40.4; H, 3.4; $\mathrm{Br}, 29.8 ; \mathrm{Cl}, 6.6 ; \mathrm{N}, 7.9$. Found: C, 40.2; H, 3.6; Br, 29.8; Cl, 6.7; N, 7.7.

1-tert-Butyl-3-o-chlorophenyl-4-p-bromophenyl-1,2,4-triazolium perchlorate (3d) was prepared by the method described for salt 3a from triazole $\mathbf{2 d}$ and tert-butyl iodide generated in situ in acetic acid. The yield of salt $3 d$ was $88 \%$. mp $195-197{ }^{\circ} \mathrm{C}$ (water). ${ }^{1} \mathrm{H}$ NMR (DMSO-d 6 , $\left.200 \mathrm{MHz}, 20^{\circ} \mathrm{C}\right): 1.75$ (s, 9H, $\left.\mathrm{CH}_{3} \mathrm{C}\right), 7.47$ (d, 2H), 7.81 (d, 2H) (J 8.6 Hz, Ar), 7.63 (m, 4H, 
Ar), 10.77 (s, 1H, CHN). Anal. Calcd for $\mathrm{C}_{18} \mathrm{H}_{18} \mathrm{BrCl}_{2} \mathrm{~N}_{3} \mathrm{O}_{4}: \mathrm{C}, 44.0 ; \mathrm{H}, 3.7 ; \mathrm{Br}, 16.3 ; \mathrm{Cl}, 14.4$; N, 8.6. Found: C, 44.2; H, 3.6; Br, 16.2; Cl, 14.5; N, 8.7.

\section{The tandem reaction of carbene 1a. 3-Phenyl-4-p-bromophenyl-5-(1-tert-butyl-3-p-} bromophenylamidin-2-yl)-1,2,4-triazole (5a) and 1-tert-butyl-3-p-bromophenylcarbodiimide (6)

Method A. A solution of carbene $1 \mathrm{a}(0.3 \mathrm{~g}, 0.84 \mathrm{mmol})$ in anhydrous decane $(0.1 \mathrm{~mL})$ was heated for $37 \mathrm{~h}$ at $130{ }^{\circ} \mathrm{C}$ and $8 \mathrm{~h}$ at $140{ }^{\circ} \mathrm{C}$, until the reaction was complete (monitored by TLC). The crystalline precipitate of $\mathbf{5 a}(0.15 \mathrm{~g})$ was filtered off and washed with a mixture of petroleum ether and benzene, 4:1 (5 mL). The mother liquor was evaporated, petroleum ether $(5 \mathrm{~mL})$ was added, and the reaction mixture was left at $-5{ }^{\circ} \mathrm{C}$ overnight. The resulting precipitate of triazole $5 \mathbf{a}(0.01 \mathrm{~g})$ was filtered off and combined with the remainder of the product. The overall yield was $0.16 \mathrm{~g}(70 \%) \cdot \mathrm{mp} 248-250^{\circ} \mathrm{C}$ (octane) (in a sealed capillary). MS (APCI) $\mathrm{m} / z$ : Calcd for $\mathrm{C}_{25} \mathrm{H}_{24} \mathrm{Br}_{2} \mathrm{~N}_{5}\left(\mathrm{MH}^{+}\right)$554. Found 554. ${ }^{1} \mathrm{H}$ NMR $\left(\mathrm{CDCl}_{3}, 200 \mathrm{MHz}, 20{ }^{\circ} \mathrm{C}\right): 1.62\left(\mathrm{~s}, 9 \mathrm{H}, \mathrm{CH}_{3} \mathrm{C}\right)$, $6.09-7.50(\mathrm{~m}, 14 \mathrm{H}, \mathrm{Ar}+\mathrm{NH}) .{ }^{13} \mathrm{C} \mathrm{NMR}\left(\mathrm{CDCl}_{3}, 50.3 \mathrm{MHz}, 20{ }^{\circ} \mathrm{C}\right): 28.4\left(\mathrm{CH}_{3} \mathrm{C}\right), 53.2$ (ipso$\mathrm{C})(t$-Bu), 114.6 (C-Br 1,2), 123.8, 127.7, 128.3 enhanced int., 129.7, 131.1, 132.2 (Ar), 123.3, 125.2, 143.6, 147.7, 150.0, 153.1 (ipso-C, C-amidine, C 5, C 3). Anal. Calcd for $\mathrm{C}_{25} \mathrm{H}_{23} \mathrm{Br}_{2} \mathrm{~N}_{5}$ : C, 54.3; H, 4.2; Br, 28.9; N, 12.7. Found: C, 54.5; H, 4.2; Br, 28.8; N, 12.7.

After the isolation of triazole 5a the mother liquor was evaporated under reduced pressure to remove the benzonitrile. The residue was dissolved in benzene and passed through a thin layer of silica gel $(40 / 100 \mu \mathrm{m})$. The solvent was evaporated and the resulting oil, which contains carbodiimide 6, was used to record the ${ }^{1} \mathrm{H}$ and ${ }^{13} \mathrm{C}$ NMR spectra. ${ }^{1} \mathrm{H}$ NMR $\left(\mathrm{CDCl}_{3}, 200 \mathrm{MHz}, 20\right.$ $\left.{ }^{\circ} \mathrm{C}\right): 1.65\left(\mathrm{~s}, 9 \mathrm{H}, \mathrm{CH}_{3} \mathrm{C}\right), 7.20(\mathrm{~d}, 2 \mathrm{H}), 7.62(\mathrm{~d}, 2 \mathrm{H})(\mathrm{J} 8.6 \mathrm{~Hz}, \mathrm{Ar}) .{ }^{13} \mathrm{C} \mathrm{NMR}\left(\mathrm{CDCl}_{3}, 50.3 \mathrm{MHz}\right.$, $\left.20{ }^{\circ} \mathrm{C}\right): 31.6\left(\mathrm{CH}_{3} \mathrm{C}\right), 57.7$ (ipso-C) $(t-\mathrm{Bu}), 117.4(\mathrm{C}-\mathrm{Br}), 124.9,132.4$ (Ar), 140.3 (ipso-C) (Ar), $135.5(\mathrm{C}=\mathrm{N})$.

Method B. A mixture of carbene $1 \mathrm{a}(0.14 \mathrm{~g}, 0.39 \mathrm{mmol})$, mother liquor $(0.14 \mathrm{~g})$ (before the isolation of benzonitrile) and decane $(0.1 \mathrm{~mL})$ was heated at $100{ }^{\circ} \mathrm{C}$ for $6 \mathrm{~h}$. The crystalline triazole 5a was isolated in similar fashion to the above-mentioned procedure. Yield $0.1 \mathrm{~g} \mathrm{(47 \% ).}$ mp. $248-250{ }^{\circ} \mathrm{C}$ (octane).

3,4-Diphenyl-5-(1-tert-butyl-3-phenylamidin-2-yl)-1,2,4-triazole (5b). This compound was synthesized in 51\% yield by the procedure described above for triazole 5a with the following temperature conditions: $150{ }^{\circ} \mathrm{C}$ for $5.5 \mathrm{~h}$ and $170{ }^{\circ} \mathrm{C}$ for $2.5 \mathrm{~h}$. mp $230-232{ }^{\circ} \mathrm{C}$ (decane) (in a sealed capillary). ${ }^{1} \mathrm{H} \mathrm{NMR}\left(\mathrm{CDCl}_{3}, 200 \mathrm{MHz}, 20{ }^{\circ} \mathrm{C}\right): 1.66\left(\mathrm{~s}, 9 \mathrm{H}, \mathrm{CH}_{3} \mathrm{C}\right), 6.18-7.21$ (m, 16H, $\mathrm{Ar}+\mathrm{NH}) .{ }^{13} \mathrm{C} \mathrm{NMR}\left(\mathrm{CDCl}_{3}, 50.3 \mathrm{MHz}, 20^{\circ} \mathrm{C}\right): 28.3\left(\mathrm{CH}_{3} \mathrm{C}\right), 52.7$ (ipso-C) $(t-\mathrm{Bu}), 121.4,122.2$, 126.3, 127.7, 127.9, 128.1, 128.6, 128.8, 129.0 (Ar), 125.7, 133.1, 143.5, 148.7, 150.4, 152.8 (ipso-C, C-amidine, C 5, C 3). Anal. Calcd for $\mathrm{C}_{25} \mathrm{H}_{25} \mathrm{~N}_{5}$ : C, 75.9; H, 6.4; N, 17.7. Found: C, $75.9 ; \mathrm{H}, 6.5 ; \mathrm{N}, 17.8$.

3,4-Di-p-bromophenyl-5-(1-tert-butyl-3-p-bromophenylamidin-2-yl)-1,2,4-triazole (5c). This compound was prepared in $81 \%$ yield by the method described above for triazole 5a with the following temperature conditions: $125^{\circ} \mathrm{C}, 5 \mathrm{~h} ; 140{ }^{\circ} \mathrm{C}, 3 \mathrm{~h}$, and $150{ }^{\circ} \mathrm{C}, 14 \mathrm{~h} . \mathrm{mp} 225-227^{\circ} \mathrm{C}$ 
(decane)(in a sealed capillary). MS (APCI) $m / z$ : Calcd for $\mathrm{C}_{25} \mathrm{H}_{22} \mathrm{Br}_{3} \mathrm{~N}_{5}\left(\mathrm{M}^{+}\right)$632. Found: 632. ${ }^{1} \mathrm{H}$ NMR $\left(\mathrm{CDCl}_{3}, 200 \mathrm{MHz}, 20{ }^{\circ} \mathrm{C}\right): 1.65\left(\mathrm{~s}, 9 \mathrm{H}, \mathrm{CH}_{3} \mathrm{C}\right), 6.08(\mathrm{~d}, 2 \mathrm{H}), 6.66(\mathrm{~d}, 2 \mathrm{H}), 6.99$ (d, 2H), $7.05(\mathrm{~d}, 2 \mathrm{H})(\mathrm{J} 8.5 \mathrm{~Hz}), 7.12-7.62(\mathrm{~m}, 4 \mathrm{H}), 6.59(\mathrm{~s}, 1 \mathrm{H}, \mathrm{NH}),{ }^{13} \mathrm{C} \mathrm{NMR}\left(\mathrm{CDCl}_{3}, 50.3 \mathrm{MHz}, 20\right.$ $\left.{ }^{\circ} \mathrm{C}\right): 28.8\left(\mathrm{CH}_{3} \mathrm{C}\right), 53.6\left(\mathrm{CH}_{3} \mathrm{C}\right), 114.8(\mathrm{C}-\mathrm{Br}, 1,2), 124.1,127.9,129.5,131.3,131.6,132.6$ (Ar), 123.8, 123.9, 124.7, 143.6, 147.9, 150.0, 152.1 (C-Br, ipso-C, Ar, C 3, C 5). Anal. Calcd for $\mathrm{C}_{25} \mathrm{H}_{22} \mathrm{Br}_{3} \mathrm{~N}_{5}$ : C, 47.5; H, 3.5; Br, 37.9; N, 11.1. Found: C, 47.4; H, 3.6; Br, 38.2; N, 11.1.

3-o-Chlorophenyl-4-p-bromophenyl-5-(1-tert-butyl-3-p-bromophenylamidin-2-yl)-1,2,4-

triazole (5d). This compound was prepared in $67 \%$ yield by the method described above for triazole 5a with the following temperature conditions: $90{ }^{\circ} \mathrm{C}, 2 \mathrm{~h} ; 110^{\circ} \mathrm{C}, 3 \mathrm{~h} ; 125^{\circ} \mathrm{C}, 5 \mathrm{~h} ; 140$ ${ }^{\circ} \mathrm{C}, 3 \mathrm{~h}$, and $150{ }^{\circ} \mathrm{C}, 5 \mathrm{~h}$. The yield of triazole $5 \mathrm{~d}$ was $0.1 \mathrm{~g}(67 \%)$. mp $267-269^{\circ} \mathrm{C}$ (decane) (in a sealed capillary). MS (APCI) $m / z$ : Calcd for $\mathrm{C}_{25} \mathrm{H}_{22} \mathrm{Br}_{2} \mathrm{ClN}_{5}\left(\mathrm{M}^{+}\right)$588. Found: 588 . ${ }^{1} \mathrm{H}$ NMR $\left(\mathrm{CDCl}_{3}, 200 \mathrm{MHz}, 2{ }^{\circ} \mathrm{C}\right): 1.61\left(\mathrm{~s}, 9 \mathrm{H}, \mathrm{CH}_{3} \mathrm{C}\right), 6.10(\mathrm{~d}, 2 \mathrm{H}), 7.03(\mathrm{~d}, 2 \mathrm{H})(\mathrm{J} 6.9 \mathrm{~Hz}), 6.42(\mathrm{~d}$, $2 \mathrm{H}, J 5.9 \mathrm{~Hz}), 7.15-7.27(\mathrm{~m}, 6 \mathrm{H})(\mathrm{Ar}), 6.55(\mathrm{~s}, 1 \mathrm{H}, \mathrm{NH}) .{ }^{13} \mathrm{C} \mathrm{NMR}\left(\mathrm{CDCl}_{3}, 50.3 \mathrm{MHz}, 20{ }^{\circ} \mathrm{C}\right)$ : $28.4\left(\mathrm{CH}_{3} \mathrm{C}\right), 53.2$ (ipso-C)(t-Bu), 123.6, 126.6, 126.8, 129.8, 131.1, 131.8, 132.0, 132.3 (Ar); 114.7 (C-Br, 1,2); 122.9, 125.7, 134.4, 143.5, 147.6, 149.3, 151.8 (ipso-C, C-Cl, C-amidine, $\mathrm{N}(4) C$, C 5, C 3). Anal. Calcd for $\mathrm{C}_{25} \mathrm{H}_{22} \mathrm{Br}_{2} \mathrm{ClN}_{5}$ : C, 51.1; H, 3.8; Br, 27.2; Cl, 6.0; N, 11.9. Found: C, 51.2; H, 3.6; Br, 27.3; Cl, 6.1; N, 11.7.

\section{1-tert-Butyl-3-phenyl-4-p-bromophenyl-5 H-1,2,4-triazoline-5,5'-spiro-1,3-diphenyl-2,4-di-}

phenyliminoimidazolidine (8). A solution of carbene $1 \mathrm{a}(0.6 \mathrm{~g}, 1.68 \mathrm{mmol})$ and diphenylcarbodiimide $(0.66 \mathrm{~g}, 3.4 \mathrm{mmol})$ in THF $(2 \mathrm{~mL})$ was stirred for $10 \mathrm{~min}$. The solvent was evaporated and the resulting crystalline product was stirred with diethyl ether, filtered off and dried to yield $1.1 \mathrm{~g}(88 \%)$ of the spiro product $8 \mathrm{mp} 97-99^{\circ} \mathrm{C}$ (benzene-diethyl ether, 1:4). MS (APCI) $m / z$ : Calcd for $\mathrm{C}_{44} \mathrm{H}_{39} \mathrm{BrN}_{7}\left(\mathrm{MH}^{+}\right)$746. Found: 746. ${ }^{1} \mathrm{H} \mathrm{NMR}\left(\mathrm{CDCl}_{3}, 200 \mathrm{MHz}, 20\right.$ $\left.{ }^{\circ} \mathrm{C}\right): 1.57\left(\mathrm{~s}, 9 \mathrm{H}, \mathrm{CH}_{3} \mathrm{C}\right), 6.59(\mathrm{~m}), 6.86(\mathrm{~m}), 7.18(\mathrm{~m})(28 \mathrm{H}, \mathrm{Ar}) .{ }^{13} \mathrm{C} \mathrm{NMR}\left(\mathrm{CDCl}_{3}, 50.3 \mathrm{MHz}\right.$, $20{ }^{\circ} \mathrm{C}$ ): $29.5\left(\mathrm{CH}_{3} \mathrm{C}\right), 57.3$ (ipso-C)(t-Bu), $119.6(\mathrm{C}-\mathrm{Br}), 121.9,122.2,124.4,125.2,125.6,125.8$, $127.3,127.7,127.9,128.1,128.2,128.5,128.9,129.7,130.0,132.0,132.7$ (Ar), 132.8, 134.8, 136.7, 138.2, 138.7, 140.9, 142.1, 145.0, 146.2, 146.6 (ipso-C, Ar). Anal. Calcd for $\mathrm{C}_{44} \mathrm{H}_{38} \mathrm{BrN}_{7}$ : C, 71.0; H, 5.1; Br, 10.7; N, 13.2. Found: C, 71.2; H, 5.0; Br, 10.7; N, 13.3.

1-tert-Butyl-3,4-diphenyl-5-cyanomethyl-5H-1,2,4-triazoline (9). A solution of carbene $1 \mathrm{~b}$ $(0.1 \mathrm{~g}, 0.36 \mathrm{mmol})$ in acetonitrile $(4 \mathrm{~mL})$ was stirred for $24 \mathrm{~h}$ at room temperature. The solvent was evaporated and the oily residue was dissolved in benzene $(5 \mathrm{~mL})$ and filtered through a thin layer of silica gel. After evaporation of the solvent the resulting residue was triturated with petroleum ether $(5 \mathrm{~mL})$ until crystallization occurred. The yield of triazoline 9 was $0.04 \mathrm{~g} \mathrm{(36 \% ).}$ mp. $108-110^{\circ} \mathrm{C}$ (acetonitrile). ${ }^{1} \mathrm{H} \mathrm{NMR}\left(\mathrm{CDCl}_{3}, 200 \mathrm{MHz}, 2{ }^{\circ} \mathrm{C}\right): 1.18\left(\mathrm{~s}, 3 \mathrm{H}, \mathrm{CH}_{3} \mathrm{C}\right), 2.74(\mathrm{~s}$, $2 \mathrm{H}, \mathrm{CH}_{2} \mathrm{C}$ ), 5.15 (s, 1H, CHN), 7.06-7.63 (m, 10H, Ar); ${ }^{13} \mathrm{C} \mathrm{NMR}\left(\mathrm{CDCl}_{3}, 50.3 \mathrm{MHz}, 20{ }^{\circ} \mathrm{C}\right)$ : $26.8\left(\mathrm{CCH}_{3}\right), 29.1\left(\mathrm{CH}_{2} \mathrm{CN}\right), 56.8\left(\mathrm{CCH}_{3}\right), 79.4(\mathrm{CHN}), 124.2,125.4,128.2,128.5,129.5,129.8$, $130.1(\mathrm{Ar}), 117.3(\mathrm{C} \equiv \mathrm{N}), 120.5($ ipso-C$-\mathrm{C}=\mathrm{N}), 143.7$ (ipso-C-4N), $151.0(\mathrm{C} 3)$. Anal. Calcd for $\mathrm{C}_{20} \mathrm{H}_{22} \mathrm{~N}_{4}$ : C, 75.4; H, 7.0; N 17.6. Found, \%: C, 75.6; H, 7.1; N 17.6.

Benzophenone-[(1-tert-butyl-3-phenyl-4-p-bromophenyl)-1,2,4-triazol-5-ylidene]azine (10). A mixture of carbene $1 \mathbf{a}(0.2 \mathrm{~g}, 0.56 \mathrm{mmol})$ in toluene $(1 \mathrm{~mL})$ and diphenyldiazomethane $(0.1 \mathrm{~g}$, 
$0.515 \mathrm{mmol}$ ) was stirred at room temperature for $0.5 \mathrm{~h}$. The resulting precipitate was filtered off, washed with petroleum ether and dried to afford $0.23 \mathrm{~g}(81 \%)$ of azine 10. mp $216-218{ }^{\circ} \mathrm{C}$ $\left(\mathrm{CH}_{3} \mathrm{CN}\right)$. MS (APCI) $m / z$ : Calcd for $\mathrm{C}_{31} \mathrm{H}_{29} \mathrm{BrN}_{5}\left(\mathrm{MH}^{+}\right)$552. Found: 552. ${ }^{1} \mathrm{H}$ NMR $\left(\mathrm{C}_{6} \mathrm{D}_{6}, 200\right.$ $\left.\mathrm{MHz}, 20{ }^{\circ} \mathrm{C}\right): 1.43\left(\mathrm{~s}, 9 \mathrm{H}, \mathrm{CH}_{3} \mathrm{C}\right), 6.7,7.2(\mathrm{~m}), 7.45(\mathrm{~m}), 7.69(\mathrm{~m})(19 \mathrm{H}, \mathrm{Ar}) .{ }^{13} \mathrm{C}$ NMR $\left(\mathrm{C}_{6} \mathrm{D}_{6}\right.$, $\left.50.3 \mathrm{MHz}, 20{ }^{\circ} \mathrm{C}\right): 27.3\left(\mathrm{CCH}_{3}\right), 59.2\left(\mathrm{CCH}_{3}\right), 126.6,126.7,127.0,127.1,127.2,128.0,128.2$, 129.1, 129.3, 129.6, 132.0 (Ar) $121.3(\mathrm{C}-\mathrm{Br}), 126.3(\mathrm{C} 3-C), 138.7$ (ipso-C-4N), 137.4, 137.5 (ipso-C-C=N), $144.2(\mathrm{C} 3), 149.6(\mathrm{C} 5) ; 153.4\left(\mathrm{CPh}_{2}\right)$. Anal. Calcd for $\mathrm{C}_{31} \mathrm{H}_{28} \mathrm{BrN}_{5}: \mathrm{C}, 67.6 ; \mathrm{H}$, 5.1; Br, 14.5; N, 12.7. Found, \%: C, 67.5; H, 5.2; Br, 14.4; N, 12.7.

1-tert-Butyl-3-phenyl-4-p-bromophenyl-1,2,4-triazol-5-one (11a). Anhydrous triplet oxygen was bubbled through a solution of carbene $1 \mathrm{a}(0.05 \mathrm{~g}, 0.14 \mathrm{mmol})$ in THF $(1.5 \mathrm{~mL})$ for $6 \mathrm{~h}$. The solvent was evaporated and the oily residue was triturated with petroleum ether. The resulting precipitate was filtered off to yield $0.03 \mathrm{~g}(58 \%)$ of triazolone 11a. $\mathrm{mp} 130-132{ }^{\circ} \mathrm{C}$ (petroleum ether). MS (APCI) $\mathrm{m} / \mathrm{z}$ : Calcd for $\mathrm{C}_{18} \mathrm{H}_{18} \mathrm{BrN}_{3} \mathrm{O}\left(\mathrm{M}^{+}\right)$372. Found: 372. ${ }^{1} \mathrm{H}$ NMR $\left(\mathrm{C}_{6} \mathrm{D}_{6}, 200\right.$ $\left.\mathrm{MHz}, 20{ }^{\circ} \mathrm{C}\right): 1.67$ (s, 9H, $\left.\mathrm{CH}_{3} \mathrm{C}\right), 7.09-7.54(\mathrm{~m}, 9 \mathrm{H}, \mathrm{Ar}) .{ }^{13} \mathrm{C} \mathrm{NMR}\left(\mathrm{C}_{6} \mathrm{D}_{6}, 50.3 \mathrm{MHz}, 20{ }^{\circ} \mathrm{C}\right)$ : $28.3\left(\mathrm{CH}_{3} \mathrm{C}\right), 58.2$ (ipso-C) $(t-\mathrm{Bu}), 127.5,127.7,128.0,129.2,132.3$ (Ar), 121.8, 138.9, 142.5 (ipso-C) (Ar), 152.4 (C 3), 159.9 (C $5=$ O). Anal. Calcd for $\mathrm{C}_{18} \mathrm{H}_{18} \mathrm{BrN}_{3} \mathrm{O}: \mathrm{C}, 58.1 ; \mathrm{H}, 4.9 ; \mathrm{Br}$ 21.5; N 11.3. Found, \%: C, 58.2; H, 5.0; Br 21.9; N 11.3.

1-tert-Butyl-3-o-chlorophenyl-4-p-bromophenyl-5H-1,2,4-triazoline (13b) and its transformation to triazole $2 d$. Powdered sodium borohydride $(0.08 \mathrm{~g}, 2.11 \mathrm{mmol})$ was added portionwise to a stirred solution of salt $\mathbf{3 d}(0.3 \mathrm{~g}, 0.611 \mathrm{mmol})$ in methanol $(10 \mathrm{~mL})$ at $20{ }^{\circ} \mathrm{C}$. After completion of the addition, the reaction mixture was stirred for $15 \mathrm{~min}$ until the reaction was complete as monitored by TLC analysis. Following this, benzene $(15 \mathrm{~mL})$ and water $(5 \mathrm{~mL})$ were added to the reaction mixture, and the two phases that had formed were separated. The organic phase was dried with anhydrous sodium sulfate. The resulting solution was evaporated to afford $0.19 \mathrm{~g}$ (79\% yield) of the oily azoline 13b. ${ }^{1} \mathrm{H}$ NMR $\left(\mathrm{C}_{6} \mathrm{D}_{6}, 200 \mathrm{MHz}, 20{ }^{\circ} \mathrm{C}\right): 1.28(\mathrm{~s}, 9 \mathrm{H}$, $\left.\mathrm{CH}_{3} \mathrm{C}\right), 5.03 \mathrm{~s}\left(\mathrm{CH}_{2} \mathrm{~N}\right), 6.40(\mathrm{~d}), 7.18(\mathrm{~d})(\mathrm{J} 8.8 \mathrm{~Hz}, 4 \mathrm{H}, \mathrm{Ar}), 7.32(\mathrm{~m}, 4 \mathrm{H}, \mathrm{Ar}) .{ }^{13} \mathrm{C} \mathrm{NMR}\left(\mathrm{C}_{6} \mathrm{D}_{6}\right.$, $\left.50.3 \mathrm{MHz}, 20^{\circ} \mathrm{C}\right): 26.0\left(\mathrm{CH}_{3} \mathrm{C}\right), 55.8\left(\right.$ ipso-C) $(t-\mathrm{Bu}), 70.1\left(\mathrm{CH}_{2} \mathrm{~N}\right), 114.6(\mathrm{C}-\mathrm{Br}), 128.4,133.6$ (ipso-CC3, C-Cl), 119.1, 127.1, 128.3, 129.9, 131.0, 131.3, 131.7 (Ar), 139.9 (ipso-CN4) (Ar), 146.2 (C 3). Anal. Calcd for $\mathrm{C}_{18} \mathrm{H}_{19} \mathrm{BrClN}_{3}$ : C, 55.1; H, 4.9; $\mathrm{Br} 20.4 ; \mathrm{Cl} 9.0 ; \mathrm{N}$ 10.7. Found, \%: C, 55.3; H, 5.0; $\mathrm{Br} 20.3 ; \mathrm{Cl} 9.1 ; \mathrm{N} 10.9$.

A solution of azoline 13b $(0.08 \mathrm{~g}, 0.198 \mathrm{mmol})$ in xylene $(2 \mathrm{~mL})$ was refluxed for $4 \mathrm{~h}$. The solvent was evaporated to give an oily product that was crystallized with small amounts of ether to afford $0.05 \mathrm{~g}$ of a crystalline mixture, from which triazole $\mathbf{2 d}$ was isolated by crystallization from toluene $(0.3 \mathrm{~mL})$. The yield of $\mathbf{2 d}$ was $0.03 \mathrm{~g}(45 \%)$. The product obtained by this method is identical to the compound described in reference 21 . 


\section{Acknowledgements}

We thank the Ukrainian Academy of Sciences for financial support and the Robert A. Welch Foundation (F-0003) for financial support of the X-ray diffraction studies. We also express gratitude to Dr. A. A. Tolmachev (Enamine Ltd, Kiev) for the chromatomass spectrometric data.

\section{Supporting Information Available}

The supplementary crystallographic data for this paper (ORTEP drawings and tables of crystallographic data for 1a and 5a) can be obtained free of charge from the Cambridge Crystallographic Data Center via www.ccdc.cam.ac.uk/data_request/cif (the deposit numbers are 648716 and 648717 , respectively).

\section{References}

1. Liu, M. T. H. Acc. Chem. Res. 1994, 27, 287.

2. Bourissou, D.; Guerret, O.; Gabbaï, F. P.; Bertrand, G. Chem. Rev. 2000, 100, 39.

3. Sole, S.; Gornitzka, H.; Guerret, O.; Bertrand, G. J. Am. Chem. Soc. 1998, 120, 9100.

4. Loncke, P. G.; Gadosy, T. A.; Peslherbe G. H. Arkivoc 2001, (xii), 179.

5. Boehler, C.; Stein, D.; Donati, N.; Gruetzmacher, H. New J. Chem. 2002, 262, 1291.

6. Belenkii, L. I.; Chuvilkin, N. D. Chem. Heterocycl. Comp. (Latvia) 1996, 1535.

7. (a) Cheng, Y.; Meth-Cohn, O. Chem. Rev. 2004, 104, 2507. (b) Nair, V.; Bindu, S.; Sreekumar, V. Angew. Chem. Int. Ed. 2004, 43, 5130. (c) Hahn, F. E. Angew. Chem. Int. Ed. 2006, 45, 1348.

8. (a) Marion, N.; Díez-González, S.; Nolan S. P. Angew. Chem. Int. Ed., 2007, 46, 2988. (b) Enders, D.; Niemeier, O.; Henseler, A. Chem. Rev. 2007 (in print). (c) Zeitler, K. Angew. Chem. Int. Ed. 2005, 44, 7506.

9. Enders, D.; Breuer, K.; Raabe, G.; Runsink, J.; Teles, J. H.; Melder, J. P.; Ebel, K.; Brode, S. Angew. Chem. Int. Ed. 1995, 34, 1021.

10. (a) Korotkikh, N. I.; Rayenko, G. F.; Shvaika, O. P. Report at the 17-th Congress of Heterocyclic Chemistry, Vienna, 1999, PO-383. (b) Korotkikh, N. I.; Rayenko, G. F.; Shvaika, O. P. Rep. Ukr. Acad. Sci. 2000, 2, 135.

11. Enders, D.; Breuer, K.; Kallfass, U., Balensiefer, T. Synthesis 2003, 8, 1292.

12. Arduengo, A. J.; Harlow, R. L.; Kline, M. J. Am. Chem. Soc. 1991, 113, 361.

13. Korotkikh, N. I.; Rayenko, G. F.; Shvaika, O. P.; Pekhtereva, T. M.; Cowley, A. H.; Jones, J. N.; Macdonald, C. L. B. J. Org. Chem. 2003, 68, 5762.

14. Korotkikh, N. I.; Shvaika, O. P.; Rayenko, G. F.; Kiselyov, A. V.; Knishevitsky, A. V.; Cowley, A. H.; Jones, J. N.; Macdonald, C. L. B. ARKIVOC 2005, (viii), 10. 
15. Dewar, M. J. S. The Molecular Orbital Theory of Organic Chemistry, McGraw Book Co., N. Y., 1969; p 216.

16. Korotkikh, N. I.; Rayenko, G. F.; Pekhtereva, T. M.; Shvaika, O. P.; Cowley, A. H.; Jones, J. N. J. Org. Chem. (Russia) 2006, 42, 12, 1833.

17. Kuhn, N.; Steimann, M.; Weyers, G. Z. Naturforsch. 1999, 54b, 427.

18. Korotkikh, N. I.; Rayenko, G. F.; Pekhtereva, T. M.; Shvaika, O. P. Rep. Ukr. Acad. Sci. 1998, 6, 149.

19. Arduengo, A. J.; Calabrese, J. C.; Davidson, F.; Dias H. V. R.; Goerlich, J. R.; Krafczyk, R.; Marshall, W. J.; Tamm, M.; Schmutzler, R. Helv. Chim. Acta 1999, 82, 2348.

20. Knishevitsky, A. V.; Korotkikh, N. I.; Cowley, A. H.; Moore, J. A.; Pekhtereva, T. M.; Shvaika, O. P.; Reeske, G. J. Organomet. Chem. 2006, in press.

21. (a) Hopkins, J. M.; Bowdridge, M.; Robertson, K. N.; Cameron, T. S.; Jenkins, H. A.; Clyburne, J. A. C. J. Org. Chem. 2001, 66, 5713. (b) Choytun, D. D.; Langlois, L. D.; Johansson, T. P.; Macdonald, C. L. B.; Leach, G. W.; Weinberg, N.; Clyburne, J. A. C. Chem. Comm. 2004, 1842.

22. Denk, M. K.; Rodezno, J. M.; Gupta, S.; Lough, A. J. J. Organomet. Chem. 2001, 617-618, 242.

23. Enders, D.; Breuer, K.; Runsink, J.; Teles, J. H. Angew. Chem., Int. Ed. 1996, 35, 2019.

24. Grimmet, M. R. In Comprehensive Organic Chemistry, Eds: D. H. R. Barton and W. D. Ollis (Rus. Edn.), M, Chemistry, 1985; Vol. 8, p 460.

25. Korotkikh, N. I.; Kiselyov, A. V.; Knishevitsky, A.V.; Rayenko, G. F.; Pekhtereva, T. M.; Shvaika, O. P. Chem. Heterocycl. Comp. (Latvia) 2005, 7, 1026. 